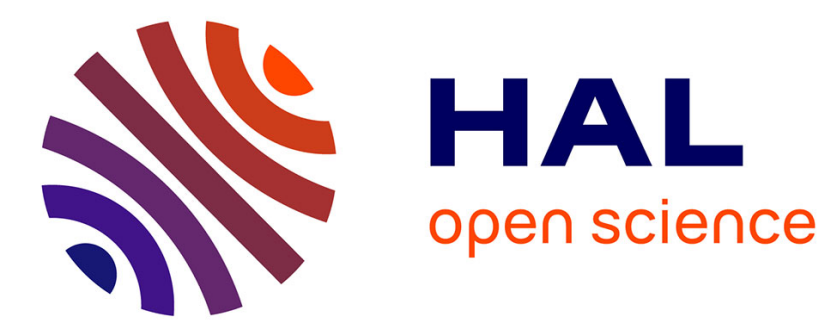

\title{
CSR firm profiles and innovation: An empirical exploration with survey data
}

Rachel Bocquet, Christian Le Bas, Caroline Mothe, Nicolas Poussing

\section{To cite this version:}

Rachel Bocquet, Christian Le Bas, Caroline Mothe, Nicolas Poussing. CSR firm profiles and innovation: An empirical exploration with survey data. 2011. halshs-00590326

\section{HAL Id: halshs-00590326 \\ https://shs.hal.science/halshs-00590326}

Submitted on 3 May 2011

HAL is a multi-disciplinary open access archive for the deposit and dissemination of scientific research documents, whether they are published or not. The documents may come from teaching and research institutions in France or abroad, or from public or private research centers.
L'archive ouverte pluridisciplinaire HAL, est destinée au dépôt et à la diffusion de documents scientifiques de niveau recherche, publiés ou non, émanant des établissements d'enseignement et de recherche français ou étrangers, des laboratoires publics ou privés. 


\section{GATE Groupe d'Analyse et de Théorie Économique Lyon-St Étienne}

93, chemin des Mouilles 69130 Ecully - France

Tel. +33 (0)4 72866060

Fax $+33(0) 472866090$

6, rue Basse des Rives 42023 Saint-Etienne cedex 02 - France

Tel. +33 (0)4 77421960

Fax. $+33(0) 477421950$

Messagerie électronique / Email : gate@gate.cnrs.fr

Téléchargement / Download : http://www.gate.cnrs.fr - Publications / Working Papers 


\title{
CSR firm profiles and innovation: An empirical exploration with survey data
}

\author{
Rachel Bocquet, IREGE, University of Savoie* \\ Christian Le Bas, Université de Lyon, Lyon, F-69003, France ; \\ Université Lyon 2, Lyon, F-69007, France ; CNRS, GATE Lyon St \\ Etienne, Ecully, F-69130, France. \\ Caroline Mothe, IREGE, University of Savoie \\ Nicolas Poussing, CEPS/INSTEAD, Luxembourg
}

\begin{abstract}
This paper explores the relationship between different Corporate Social Responsibility (CSR) strategies and innovation. Using a survey carried out on CSR behavior of Luxembourg firms, we found two types of firms as far as CSR practices are concerned. Cluster 1 firms adopted CSR practices to achieve economic goals without resorting to the formalization of these practices. In contrast, cluster 2 firms "learn CSR by doing" and by establishing CSR procedures and tools. Then we match Community Innovation Survey (CIS) data and specific data collected on CSR clusters. We estimate Logit models to explain the different types of innovation (product, process, organizational). In comparison with the firms which don't adopt CSR, firms in Cluster 1 are more innovative in terms of product and process once we control for firm characteristics and innovation drivers while firms in cluster 2 tend to reject innovation in process and adopt organizational innovation. These results, which show the link between the various CSR practices and innovation types, have important consequences in terms of managerial recommendations and public policy support for innovation.
\end{abstract}

Key words: Corporate Social Responsibility, Innovation, Organizational, Practices, Product, Process

\section{Résumé}

Cet article étudie les relations entre la responsabilité sociale des entreprises (RSE) et l'innovation. En utilisant les résultats d'une enquête menée auprès d'entreprises du Luxembourg on trouve qu'il y a deux groupes de firmes en matière de comportement de RSE. Les firmes du groupe 1 adoptent des pratiques de RSE pour mener à bien des finalités économiques sans toutefois formaliser leurs pratiques. En revanche les firmes du groupe 2 "ont appris" et ont établi des procédures et des outils de RSE. Ensuite on applique aux deux groupes de firmes des données issues des enquêtes innovation européennes. On estime des modèles Logit pour expliquer differents types d'innovation (produit, procédé, organisationnelle). On montre après avoir contrôler des effets associés aux différents moteurs de l'innovation, que les firmes du groupe 1 sont plus innovantes en termes de produit et de procédé alors que les firmes du groupe 2 tendent à adopter des innovations organisationnelles mais à exclure des innovations de procédé. Ces resultats montrant qu'il y a des liens entre des types de pratiques de RSE et des types innovations, ont d'importantes conséquences pour la définition des stratégies d'entreprises et des politiques publiques de soutien à l'innovation.

Mots clefs:Responsabilité sociale des entreprises, Innovation, Organisation, Pratiques, Produit, Procédé.

\footnotetext{
* for all correspondence:rachel.bocquet@univ-savoie.fr
} 


\section{Introduction}

Corporate Social Responsibility (CSR) has received greater attention in the past decade. The many recent special issues dedicated to the subject attest to the fact that CSR has become an important phenomenon at the firm level. The literature has focused on various dimensions (and measurement criteria) of CSR: the determinants of CSR engagement, the specificities of CSR in SMEs, the link between CSR and company performance or value creation. Our objective in this study is to explore the relationship between CSR and innovation. Prior research has identified a potentially strong relationship between CSR and innovation (McWilliams and Siegel, 2000). Several authors have highlighted its bidirectional nature (Moore and Spence, 2006; Husted and Allen, 2007a, 2007b). However, this relationship remains to be explored as theoretical and empirical researches remain scarce. When empirical research exists, it remains of qualitative nature because of the lack of databases on CSR.

We here merged an original CSR firm-level database with Community Innovation Survey data (CIS). These two databases are related to Luxembourg firms. We addressed the following questions: what practices of CSR do companies adopt and what are the potential links between these distinct practices of CSR and the different types of technological innovation (product, process, organization) ${ }^{1}$ ?

We thus aimed at partially filling this gap and contribute to a better understanding of the complex relationship between innovation and CSR. We propose an empirical methodology in order to classify firms according to their CSR practices. The characterization of firms' practices is inherited from a strategic approach of CSR that clearly introduces the link between CSR and innovation. As far as CSR practices are concerned, our cluster analysis shows that two CSR firm profiles (CSR cluster thereafter) emerge. The aim of the paper is to test whether the belonging to a CSR cluster is a key determinant of a firm's (type of) innovation. Results show that firms that attempt to endorse socially responsible business practices are not automatically engaged in product, process or organizational innovations, in line with Le Bas et al. (2010). And the type of CSR firms are engaged in is related to the type of innovation the firm is engaged in.

The paper is organized as follows. Section 2 provides an analytical framework related to CSR practices. Section 3 sets out the data and the sample. Section 4 provides the cluster analysis, Section 5 the results stemming from the estimated Logit models. The final section concludes, and presents the limitations of the study and some avenues for further research.

\section{CSR profiles: a framework}

On an academic ground, the relationship between CSR and innovation has still not been evidenced. The literature on CSR provides an understanding of the process by which "companies integrate social and environmental concerns to their business operations and in their interactions with stakeholders on a voluntary basis" (Commission of the European Communities, 2001: 6). The stakeholder theory identifies CSR practices and addresses the link between CSR and "conventional" firm performance (profitability, stability, growth). Donaldson and Preston (1995: 67) noted that "it establishes a framework for examining the connections, if any, between the practice of stakeholder management and the achievement of various corporate performance goa/s". However, these approaches do not explicitly address innovation performance.

The extension by the strategic management literature offers an interesting theoretical perspective for reconciling CSR and innovation, but without detailing CSR practices.

\footnotetext{
${ }^{1}$ As shown by previous studies, these different types of innovation do not have the same economic consequences in terms of market share and/or profit rate, and clearly induce different levels of economic performance.
} 
Combining both streams of literature, we explore the link between these CSR practices and firm innovation performance.

\section{CSR and stakeholder theory}

The stakeholder theory is generally viewed as the conventional theory for CSR. It places economic objectives in the foreground when incorporating stakeholders' objectives into business. Stakeholders are the central parts of this approach, which can prove useful in order to explain and guide companies' operations (Donaldson and Preston, 1995). The CSR approach is not only the final result of a process, it is also a process in itself that must be considered in all decision-making and must be evaluated and measured. The stakeholder theory thus stresses the necessity to formalize CSR processes. CSR formalization implies the availability of written documents describing CSR practices, especially in relation with the various stakeholders, codified processes, establishment of CSR targets and objectives, etc.

The main criticism of this approach, addressed by researches (e.g. Porter and Kramer, 2006) in the strategic management field, lies in the fact that it views external stakeholders as applying constraints on the firm, rather than as acting as a lever for innovation. At best, innovation is considered as a by-product. Indeed, its objective is not to view CSR as a potential value creating strategy from which the full integration of stakeholders is considered as a key determinant of innovation.

\section{Strategic management literature}

This approach explicitly incorporates innovation and views it as an endogenous force that drives new resource combinations in order to sustain a competitive advantage. Porter and Kramer (2006) "have asserted that CSR can provide opportunities for innovation" (Husted and Allen, 2007a: 597). CSR and strategic processes are mutually reinforcing. Engaging in social, societal or environmental programs appears to provide valuable resources for the firm (Sharma and Vredenburg, 1998) and to foster innovation (Husted and Allen, 2007b). Employee involvement seems to play a key role in environmental strategy for instance, as it enhances process innovation (Sharma and Vredenburg, 1998). Nidumolu et al. (2009) stated that CSR and sustainability are now considered as "key drivers for innovation" (p. 57). These (mainly theoretical) studies therefore explicitly indicate that CSR can lead to innovation.

Some authors distinguish different types of CSR strategies and levels. For Porter and Kramer (2006), for instance, CSR is seen either as a response ("responsive CSR") or as a strategic lever ("strategic CSR"). Responsive CSR corresponds to the "0 level" of CSR, "acting as a good corporate citizen, attuned to the evolving social concerns of stakeholders, and mitigating existing or anticipated adverse effects from business activities' (Porter and Kramer, 2006: 85). Through the implementation of best practices, responsive CSR creates goodwill, improves relations with stakeholders, and allows to identify the social and environmental impacts of the unit's activities throughout the value chain. CSR practices are reflected primarily in organizational innovation. However, effects are quite limited in terms of (incremental) innovation. On the other hand, strategic CSR goes beyond the implementation of best practices. It is based on the exploitation of complementarities between inside-out and outside-in linkages in order to achieve a unique and distinctive position as compared to competitors ('lower cost, better service'). From this point of view, the relationship between CSR and process and product innovations is well established: strategic CSR based on a symbiotic relation between society and a companies' own competitiveness appears to be a main determinant for (radical) innovation.

Porter and Kramer (2006) characterize the various levels according to the firm's "strategic intent" (Hamel et Prahalad, 1989). They then establish the link between each type of CSR and firm innovation performance. However, nothing is said on the CSR practices and their characteristics. We therefore aim to complete this framework by a better characterization of CSR profiles. 
In order to achieve that, we relied on the strategic approach of Burke and Logsdon (1996), who proposed five CSR dimensions that may affect a firm's ability to create value (including through product, process innovation and organizational innovations). To our knowledge, no other study has characterized strategic CSR. Their model introduces the following key dimensions (Burke and Logsdon, 1996: 497) to characterize CSR practices as key determinants of innovation:

- centrality: "closeness of fit to the company's mission and objectives";

- proactivity: "degree to which the program is planned in anticipation of emerging social trends and in the absence of crisis;

- voluntarism: "the scope for discretionary decision-making and the lack of externally imposed compliance requirements";

- visibility: "observable, recognizable credit by internal and/or external stakeholders for the company";

- specificity: "ability to capture private benefits by the company".

Although this latter dimension seems to close to the dependent variable, i.e. "value creation" ("identifiable, measurable economic benefits that the firm expects to receive", Burke and Logsdon, 1996: 497), we included it in order to apprehend whether firms have an asserted economic objective for their CSR involvement.

Investigations of the CSR concept has been mainly based on qualitative case studies (e.g. Jenkins, 2006; Moore et al., 2009; Murillo and Lozano, 2006; Tencati et al., 2004, etc.). This type of methodology is well adapted to the description of CSR practices. However, a quantitative methodology is best suited to analyze the link between CSR and innovation which remains unstudied as datasets on CSR remain rare. In this paper, we merged an original CSR firm-level dataset with CIS data.

\section{Data and sampling}

We use an empirical procedure which consists of two steps. In Step 1, we realize a nonhierarchical cluster analysis to classify the firms in relation to their CSR practices. The database on CSR practices of Luxembourg firms, elaborated in 2008 by the CEPS/INSTEAD of Luxembourg, comprises 1144 firms, which is representative of the Luxembourg firm population. On those, we retained those 209 firms having responded Yes $=1$ to the question: "Is your firm active in the domain of CSR?".

In Step 2, we focused on the link between CSR practices and types of innovation (product, process and organizational) since these types of innovation do not have the same effects in terms of economic performance. With respect to the determinants of types of firm innovation, some factors are common to the types of innovation but others are specific (Cabagnols and Le Bas, 2001). We used data from two main sources though their coverage is somehow different: the previously mentioned CSR survey and the Community Innovation Survey (CIS 2006). This last survey is made in Luxembourg by the CEPS/INSTEAD in collaboration with the Luxembourg National Institute of Statistic (STATEC). CIS collects information about product and process innovation as well as organisational and marketing innovation during the three-year period 2004 to 2006 inclusive. Most questions cover new or significantly improved goods or services or the implementation of new or significantly improved processes, logistics or distribution methods. The survey covers also Knowledge Management practices and Research \& Development. Data also provide information on general economic firms' features: economic sector, number of employees, group membership, characteristic of the competition context and the market.

After merging these two databases, we obtained a sample of 266 firms that have fulfilled both the CSR and CIS questionnaires. This sample is weighted in order to produce representative results of the population of firms. The calibration has been carried out, with the CALMAR macro from French National Institute of Statistic (INSEE), based on auxiliary information: number of firms per sector and number of employees per sector. 
The weighted sample is composed of $72.6 \%$ of small firm (with more than 10 employees and less than 50). Less than a quarter of the total population is composed by medium sized enterprises which the number of employees is between 50 to 249 employees $(22.1 \%)$. The proportion of firms with more than 249 employees is $5.3 \%$. Data shows that $46.7 \%$ of the firms are part of a group. Concerning innovation, we see that $36.1 \%$ of the firms implement innovation product, $33.8 \%$ implements innovation process, and $47.1 \%$ implements innovation product or innovation process. Organizational Innovation concerns $53.4 \%$ of the population.

Concerning CSR profile, our population is composed by $22.5 \%$ of firms which adopt CSR, $13.3 \%$ plan to adopt CSR and a large majority (64.2\%) doesn't adopt CSR practices $^{2}$. Finally each firm in our sample may innovate (or not) in a particular type of innovation and implement (or not) CSR. We consider CSR as an important implication for the understanding of innovation determinants ${ }^{3}$ and want to test this idea. As a consequence we estimated Logit models in order to analyze the possible relationship between innovative behavior and type of CSR practices.

For our empirical study the data have constraints. They are twofold. On the one hand we have not enough data on some factors that are considered as important determinants of a particular type of innovation, on the other the relatively small size of the firms sample do not enable us to put in our regressions a lot of variables. For these reasons we focus our approach on the main explanatory factors of firms' innovation.

\section{A cluster analysis for CSR profiles (Step 1)}

Our survey data describe CSR practices according to the five identified dimensions (Burke and Logsdon, 1996):

- centrality ("closeness of fit to the company's mission and objectives") has been measured by two binary variables: the existence or not of documents describing values and motivations in terms of social and environmental concerns ( $\mathrm{C} 1$ in Table 3$)$, and whether the firm describes - or not - its CSR practices in its annual report, in a dedicated report, or in the website (RSED);

- specificity ("ability to capture private benefits by the firm") is measured through 3 variables on a 4 item Likert scale ranging from 1 (no perceived benefits) to 4 (strong perceived benefits: to attract new clients (B8CLT), to enhance the firm's image (B8IMAFG), differentiation from competition (B8COMP);

- proactivity ("degree to which the program is planned in anticipation of emerging social trends and in the absence of crisis") is measured through two binary variables: existence or not of CSR action planning and agenda $(\mathrm{C} 10, \mathrm{C} 16)$;

- voluntarism ("the scope for discretionary decision-making and the lack of externally imposed compliance requirements") is measured through the binary variable assessing whether the firm has identified - or not - the stakeholders for its CSR actions (C6);

- visibility ("observable, recognizable credit by internal and/or external stakeholders for the company") is measured through the binary variable assessing whether the firm has - or not - an either external or internal communication plan (RSEOU).

A principal component analysis ${ }^{4}$ was conducted on these nine core variables that operationalize the CSR dimensions (C1; RSEOU; C10; C16; RSED; C6; B8CLT; B8IMAGF; B8COMP). The MSA test (Hair et al., 1998) showed that all the variables were good candidates for a PCA (MSA values $>0.5$ ). In addition, KMO and Bartlett's test of sphericity met common standards $(\mathrm{KMO}=0.55$ and $\mathrm{p}<0.001)$. The PCA uncovered two factors giving a good summary of the theoretical dimensions (accounting for $49,8 \%$ of the total variance).

A non-hierarchical cluster analysis was then carried out based on the scores revealed by the factor analysis. In order to determine the final number of clusters, we used three usual criteria: (i) the statistical accuracy of the classification measured by the ratio of within

\footnotetext{
${ }^{2}$ For summary statistics of principal variables (mean, std dev, min, max) see table in the appendix 1.

${ }^{3}$ For a literature review on the determinants of types of innovation see Damanpour (2010).

${ }^{4}$ We do not present the results of the principal component analyses here as they are only preparatory stages for our cluster analyses. There are available on request.
} 
cluster and between-clusters variances (Fisher's test), (ii) the number of firms per cluster, and (iii) the economic significance of the clusters identified. According to these criteria, the version with two clusters of CSR practices is preferred ${ }^{5}$. To interpret these two clusters, we calculated the mean of each CSR indicator in each cluster (see Table 3 ).

The results may be interpreted by comparing the means in each cluster. The two CSR clusters are defined as follows:

- In Cluster 1 (114 firms), firms are very economic objective-oriented, and not inclined towards formalization. They have high economic objectives associated to CSR although they do not formalize their CSR practices. The CSR is meant for the firm's benefit only, and is less oriented towards the stakeholders' benefits. These are more a means than an end in this type of approach;

- In Cluster 2 (95 firms), firms "learn by doing" by establishing procedures and tools as far as CSR is concerned. They do not have any asserted economic objective, the main benefit they want to retain from their CSR involvement is the firm's image - which is still lower that the same objective for the other class of firms. However, they clearly identify their stakeholders and have formal documents where their CSR action is described. They want visibility, and "say what they do".

\section{Table $3 \quad$ CSR clusters}

\begin{tabular}{|c|c|c|c|c|c|c|c|c|c|c|}
\hline \multicolumn{2}{|c|}{ Cluster } & $\mathrm{C} 1$ & RSEOU & RSED & B8CLT & B8IMAFG & B8COMP & $\mathrm{C} 10$ & $\mathrm{C} 16$ & $\mathrm{C} 6$ \\
\hline & Mean & 1,70 & 1,6228 & 1,7788 & 3,0187 & 3,8198 & 3,5273 & 1,96 & 1,82 & 1,46 \\
\hline & $\mathrm{N}$ & 114 & 114 & 113 & 107 & 111 & 110 & 113 & 110 & 114 \\
\hline \multirow[t]{2}{*}{2} & Mean & 1,31 & 1,2737 & 1,4211 & 2,5435 & 3,4787 & 2,9787 & 1,51 & 1,51 & 1,13 \\
\hline & $\mathrm{N}$ & 95 & 95 & 95 & 92 & 94 & 94 & 95 & 91 & 95 \\
\hline \multirow[t]{2}{*}{ Total } & Mean & 1,52 & 1,4641 & 1,6154 & 2,7990 & 3,6634 & 3,2745 & 1,75 & 1,68 & 1,31 \\
\hline & $\mathrm{N}$ & 209 & 209 & 208 & 199 & 205 & 204 & 208 & 201 & 209 \\
\hline
\end{tabular}

NB : The mean is in bold value when it is significantly higher in the considered cluster.

These preliminary results echo Porter and Kramer's (2006) distinction between firms with strategic and responsive CSR. Cluster 2 firms are in line with the strategic vision. Indeed, Porter and Kramer (2006) emphasize the fact that, for these firms, stakeholders are key and taken into account as strategic resources. On the contrary, for Cluster 1 firms, communicating about CSR is more important than "doing things". For these responsive firms, stakeholders are not taken into account. They have economic objectives for CSR but do not give themselves the means to really implement CSR practices.

\footnotetext{
${ }^{5}$ For all comparisons of variances, Fisher's test is significant at the 0.000 level and indicates a good differentiation between firms.
} 


\section{Estimating the relationship between CSR firm profiles and innovation (Step 2)}

Our intent is to determine whether there is a relationship between the different CSR profiles (our two clusters) and the various types of innovation (product, process, organizational). We here present the variable definition and the estimations.

\subsection{Variable definition}

\section{Dependent variables: three innovation types}

The three dependent variables are product, process and organizational innovations, thus adapting Burke and Logsdon's model (1996) where the dependent variable is "value creation". We here focused on a more precise aspect of value creation, i.e. innovation, in line with Husted and Allen (2007a: 597) who assert that "value creation is necessarily about innovation".

The variables are those found in the 2006 Community Innovation Surveys. The questions for product and process innovations are the following: "during the years 2004 to 2006, did your firm introduce a new or significantly improved product (good or service) or process for making or supplying them" (INPDGD), and "during the years 2004 to 2006, did your firm introduce one or several of the following processes". Process innovation (INSPSPD) includes significant changes in the way that goods or services are produced or provided, again differentiating between processes new to the business only or also new to the industry.

The third variable relates to the introduction of a new of significantly improved organization (INNORG). Organizational innovation encompasses four types of practices: (a) New business practices for organizing work or procedures (i.e. supply chain management, business re-engineering, lean production, quality management, education/training systems, etc.); (b) new knowledge management systems designed to improve information use or exchange, knowledge and skills within the enterprise or to collect and interpret information from outside the enterprise; (c) new methods of workplace organization for distributing responsibilities and decision-making (i.e. team work, decentralization, integration or de-integration of departments, etc.) and (d) new methods of organizing external relations with other firms or public institutions (i.e. first use of alliances, partnerships, outsourcing or sub-contracting, etc.) (OECD, 2005).

\section{Independent variables}

In order to get the effects of each CSR profile, we introduced the two CSR profiles inherited from the classification procedure. These two variables are denoted cluster_1 and cluster_2. The probability to innovate also depends on a mix of firm-specific characteristics and sector configurations (Cohen, 1995). Our empirical model takes into account five main innovation drivers: technological (or innovative) opportunities, firm's capabilities, incentives to exploit technological opportunities, organizational arrangements and appropriability conditions:

- Firm's capabilities are acknowledged as crucial, in the dynamic capabilities' approach, for the firm's long term success (Teece and Pisano, 1994) and for their innovative performance in the evolutionary approach (Nelson and Winter; 1982). Having a strong knowledge base includes an R\&D capacity and a well-trained workforce (Archibugi and Lundvall, 2001). As R\&D expenditures are not mentioned in our databases (moreover, R\&D expenditures do not always capture the innovation efforts, especially for small firms, see Mohnen and Mairesse, 2010), we considered the proportion of employees with higher education degree (EDUCATION) as a good proxy to estimate the level of the human capital dedicated to innovation;

- The incentives to exploit technological opportunities also are an important innovation driver. To control for competitive intensity, we have included the variable (NMARCON) which is a dummy variable and takes into account the fact that the competition of the market where the firm is operating in is very intense; 
- The two other drivers (technological opportunities and appropriability conditions) are crucial for generating and maintaining the rents stemming from leadership in technological activities. We encompassed such effects through sector (manufacturing and services, INDUS) and firm size (T1: from 10 to 49 employees, T2: from 50 to 249 employees, T3: more than 250 employees, according to the European definition) variables. Indeed, it has been pointed out (on the effects on firm size, see Cohen, 1995) that large firms have the means for exploiting the opportunities coming from outside. And appropriability conditions are related to size: in general, large firms use the patent system. The conventional wisdom considers that firm size matters (while the topic is controversial). Large firms have enough resources to invest in technological activities. Small firms have more limited means but some are very innovative in high-technology sectors in particular (see Cohen, 1995).

- The organizational arrangements and mechanisms through which technological advances are implemented (Dosi, 1997) is a large category which includes the own firm organization as well as the institutional industrial background. However, we have no good proxy for this factor. As a consequence we drop it from our quantitative analysis.

All variables and their definition are provided in Table 2. The correlations between variables are given in appendix 2 .

Table 2 List of variables

\begin{tabular}{|c|c|}
\hline Variables & Description \\
\hline INPDGD & Product innovation : the firm introduces new or significantly improved goods \\
\hline INSPSPD & $\begin{array}{l}\text { Process innovation : the firm introduces new or significantly improved methods of } \\
\text { manufacturing or producing goods or services }\end{array}$ \\
\hline INORG & $\begin{array}{l}\text { Organizational innovation: the firm introduces a new organizational method in their } \\
\text { enterprise's business practices (including knowledge management), workplace } \\
\text { organization or external relations that has not been previously used by your enterprise. }\end{array}$ \\
\hline CLUSTER_1 & $\begin{array}{l}\text { Firms are very economic objective-oriented, are not inclined towards formalization. They have } \\
\text { high economic objectives associated to CSR although they do not formalize their CSR } \\
\text { practices. The CSR is meant for the firm's benefit only, and is less oriented towards the } \\
\text { benefits for stakeholders. The stakeholders are more a means than an end for this type of } \\
\text { approach. }\end{array}$ \\
\hline CLUSTER_2 & $\begin{array}{l}\text { Firms "learn by doing" by establishing procedures and tools as far as CSR is concerned. They } \\
\text { do not have any asserted economic objective, the main benefit they want to retain from their } \\
\text { CSR involvement is the firm's image - which is still lower that the same objective for the other } \\
\text { class of firms. However, they clearly identify their stakeholders and have formal documents } \\
\text { where their CSR action is described. They want visibility, and "say what they do". }\end{array}$ \\
\hline PLAN_RSE & Plan to adopt CSR behavior \\
\hline NO_RSE & Don't adopt and don't plan to adopt CSR behavior \\
\hline $\mathrm{T} 1$ & The enterprise's total number of employees is between 10 to 49 \\
\hline $\mathrm{T} 2$ & The enterprise's total number of employees is between 50 to 249 \\
\hline T3 & The enterprise's total number of employees is more than 249 \\
\hline INDUS & Belong to the manufacturing sector \\
\hline GROUPE & The firm is a part of enterprise group \\
\hline EDUCATION & $\begin{array}{l}\text { Percentage of employees with Higher education (include post-secondary college diplomas and } \\
\text { university graduates) }\end{array}$ \\
\hline NMARCON & the competition of the market you were operating in is very intense \\
\hline
\end{tabular}

In bold, the main dependent variables. 


\subsection{Model and estimation}

The natural modeling for answering if a set of variables as an impact on the decision to innovate is the Logit model. It is standard in empirical works that deal with firm behavior. We used a Logit model $^{6}$ for each type of innovation (product, process, organizational). The models account for the probability that a firm implements each type of innovation. The set of regressors are the same for each. The data are withdrawn from CIS 2006 and CSR Survey Luxembourg. The belongings to a cluster set up our core variables. We added a dummy variable (PLAN_RSE) to take into account the fact that some firms expect to implement CSR in the not too distant future (as a consequence, they are not included in the dummy variables CLUSTER_1 and CLUSTER_2) and a dummy variable (NO_RSE, which the reference variable) to take into account firms which do not adopt CSR. The other control variables match the identified innovation drivers (Dosi, 1997). Table 3 below provides the coefficients estimates through their marginal effects on the probability to innovate. The percentage of concordance must be considered as the goodness-of-fit.

One important problem with our analysis is that the decision to adopt product innovation may be related to the decision to implement process innovation. In this case the random error terms in the two equations are assumed to be correlated. Their covariance equals $\rho$. We need to perform a statistical test for $\rho=0$ provides an indication of the interdependence of the two adoption decisions. Appendix 3 displays this regression.

\section{Results}

We here explain whether the belonging to one cluster has an impact on the probability to implement a specific type of innovation. Thus, when a coefficient (related to clusters) is not significant, it does not mean that the firms from this cluster do not implement this type of innovation. In fact, in general they do, but in a proportion that does not differ statistically significantly from the proportion of innovating firms in the other cluster.

Results show that cluster 2 firms (relatively to firms which don't adopt CSR) implement more product innovation and process innovation whereas cluster 1 firms are more reluctant to implement organizational innovation. Cluster 2 firms are thus specialized in product innovation, and cluster 1 firms push away from organizational innovation.

All these results hold in the context of the Logit model estimated here, with the set of our control variables. The fact that the dummy for industry is significant for two models out of three means that manufacturing firms, not surprisingly, innovate more in product and process than service firms (who are generally more into organizational innovation). It is also not surprising that the variable "Education" plays a significant role for all three types of innovation. Firm size has an impact on the probability to adopt innovation. In more details, relatively to a medium company, be a small company negatively affects the probability of adopting a product innovation and organizational innovation; be a large company positively affects the probability of adopting a product innovation. Belonging to a group and belonging to a market where the competition is very intense, affect positively the probability to innovate in product and process. An important proportion of employees with Higher education in the firms have a positive effect on every types of innovation.

The estimation of the bivariate Logit model (appendix 3) shows clearly that the covariance of error terms $(\rho)$ is significantly different from zero. In other terms the two decisions (related to product and process innovation) are linked. But the main point is the coefficients have the same sign than the coefficients related to the same variables in the set of estimation in Table 3. To put it simply the bivariate Logit model confirms the results previously found.

\footnotetext{
${ }^{6}$ Probit and Logit models generally yield relatively similar results (Morimune, 1979, Davidson and MacKinnon, 1984).
} 


\begin{tabular}{|c|c|c|c|}
\hline & \multicolumn{3}{|c|}{$\begin{array}{c}\text { Logit Model } \\
\text { Marginal effect (standard error) }\end{array}$} \\
\hline & INPDGD & INSPSPD & INORG \\
\hline CLUSTER_1 & $\begin{array}{l}0.6265^{* * *} \\
(0.2106)\end{array}$ & $\begin{array}{l}0.7119^{* * *} \\
(0.2158)\end{array}$ & $\begin{array}{l}-0.8232 \\
(0.2052)\end{array}$ \\
\hline CLUSTER_2 & $\begin{array}{c}0.1304 \\
(0.1929)\end{array}$ & $\begin{array}{c}-0.9039 * * * \\
(0.2193)\end{array}$ & $\begin{array}{c}1.5528^{* * *} \\
(0.2132)\end{array}$ \\
\hline PLAN_RSE & $\begin{array}{c}-0.5537^{* * *} \\
(0.1951)\end{array}$ & $\begin{array}{l}-0.2986 \\
(0.1892)\end{array}$ & $\begin{array}{c}0.4735^{* * *} \\
(0.1687)\end{array}$ \\
\hline NO_RSE & Réf. & Réf. & Réf. \\
\hline T1 & $\begin{array}{c}-0.4126^{* * *} \\
(0.1576)\end{array}$ & $\begin{array}{l}-0.1072 \\
(0.1631)\end{array}$ & $\begin{array}{c}-0.5479^{* * * *} \\
(0.1524)\end{array}$ \\
\hline $\mathrm{T} 2$ & Réf. & Réf. & Réf. \\
\hline T3 & $\begin{array}{l}0.6099 * * \\
(0.2886)\end{array}$ & $\begin{array}{l}-0.1626 \\
(0.2965)\end{array}$ & $\begin{array}{c}0.3337 \\
(0.3019)\end{array}$ \\
\hline INDUS & $\begin{array}{l}0.6465^{* * *} \\
(0.1550)\end{array}$ & $\begin{array}{l}0.7988^{* * *} \\
(0.1606)\end{array}$ & $\begin{array}{l}-0.0532 \\
(0.1426)\end{array}$ \\
\hline GROUPE & $\begin{array}{l}0.3870^{* * *} \\
(0.1346)\end{array}$ & $\begin{array}{c}1.1581^{* * *} \\
(0.1414)\end{array}$ & $\begin{array}{l}-0.0624 \\
(0.1255)\end{array}$ \\
\hline EDUCATION & $\begin{array}{l}2.4097 * * * \\
(0.2105)\end{array}$ & $\begin{array}{c}2.2604 * * * \\
(0.2155)\end{array}$ & $\begin{array}{c}1.4991^{* * *} \\
(0.2018)\end{array}$ \\
\hline NMARCONC & $\begin{array}{c}0.4096^{* * *} \\
(0.1300)\end{array}$ & $\begin{array}{c}0.7520^{* * *} \\
(0.1363)\end{array}$ & $\begin{array}{l}0.2108^{*} \\
(0.1202)\end{array}$ \\
\hline Intercept & $\begin{array}{c}-1.6785^{* * *} \\
(0.2039)\end{array}$ & $\begin{array}{c}-2.5072 * * * \\
(0.2232)\end{array}$ & $\begin{array}{l}-0.1467 \\
(0.1830)\end{array}$ \\
\hline Sample size & 1431 & 1431 & 1431 \\
\hline -2 Log-likelihood & 1623.782 & 1523.670 & 1804.485 \\
\hline$\%$ of concordance & 74.3 & 61.7 & 69.0 \\
\hline
\end{tabular}

$*$ coef. significant at a threshold of $10 \%,{ }^{* *}$ coef.: $5 \%, * * *$ coef.: $1 \%$.

\section{Conclusion}

The objective of this paper was to assess whether firm CSR profiles and practices were related to particular types of innovation. The CIS data allowed us to retain the "classical" typology of innovation strategies: product, the process, and organizational. Our results show that firms in Cluster 2, those that formalize CSR and involve their stakeholders, thus having a strategic orientation to CSR, are more innovative in terms of product once we control for firm characteristics and innovation drivers. This result is not surprising and tends to empirically validate Porter and Kramer's (2006) theoretical assumptions. The fact that process innovation does not appear to be significant could be explained by the fact that these firms are more oriented towards client satisfaction, thus towards an external usage of CSR practices - more than an internal one focused on cost reduction. Cluster 2 firms, by having a clear value creation strategy oriented towards the customer, tend to privilege organizational innovation over process innovation. Interestingly, and confirming this strong orientation towards formalization of Cluster 2 firms, the firms in Cluster 1 highly reject organizational innovation (which often entails formal procedures and practices). These results are in line with previous findings showing that firms implementing CSR practices are more inclined to proceed to technological innovation (Bocquet and Mothe, 2010; Le Bas et al., 2010). We here have gone further in the analysis by considering the types of innovation carried out.

These results entail important implications for theory in two main directions. First, our results tend to empirically confirm previous theoretical assumptions on the link between CSR practices and innovation, however looking much more carefully at this link. Indeed, 
in order to foster product innovation, firms should adopt formalized CSR practices and establish procedures and tools. Considered as having "strategic CSR" (Porter and Kramer, 2006), they clearly identify their stakeholders and are focused on that external visibility, "saying what they do" in formal documents where their CSR practices are well described.

Our results are of considerable importance to managers who want to either use CSR practices to enhance technological (and especially product) innovation, or their technological innovation to introduce CSR practices. It has been seen that the strategic orientation is key in both areas. These entails major implications for public policy support to innovation and/or to CSR firm engagement, link which calls for further studies on complementarities (Mohnen and Roller, 2005) between CSR practices and innovation types. This would mean that packages of policies are needed to help firms to engage in either CSR or innovation processes.

Our paper is not exempt from some limitations. The main one relates to the specific economic structure of Luxembourg, thus of our sample, where service firms are mostly big and established firms such as in banking, while the manufacturing sector is composed mainly of SMEs. Future research should therefore replicate this study in countries where the two sectors have similar features, and/or deal with larger samples in order to conduct separate analyses on manufacturing and service industries - which was not possible here. Another extension would be to estimate models with more complex structures, for instance to estimate the probability to implement in the same time product and process innovation. Finally, longitudinal data would be required to determine the causality between CSR and innovation.

\section{References}

Archibugi D. \& Lundvall B. 2001. The Globalizing Learning Economy. Oxford University Press. Oxford

Bocquet R. \& Mothe C. 2010. RSE et innovation: les spécificités des PME, ADERSE, La Rochelle, march.

Burke L. \& Logsdon M. 1996. How Corporate Social Responsibility Pays Off, Long Range Planning, 29(4): 495-502.

Cabagnols A. \& Le Bas C. 2001. The Determinants of the Type of Innovative Behaviour at the Firm Level, in A. Kleinknecht, P. Mohnen (eds) Innovation and Firm Performance : Econometric Explorations of Survey Data, Palgrave, 112-149.

Cohen W. 1995. Empirical Studies of Innovative Activity, in P. Stoneman, Handbook of the Economic of Innovation and Technological Change, Blackwell.

Damanpour F. 2010. An Integration of Research Findings of Effects of Firm Size and Market Competition on Product and Process Innovations, British Journal of Management, 21(4): 996-1010.

Davidson R. \& MacKinnon J.G. 1984. Convenient Tests for Logit and Probit Models, Journal of Econometrics, 25: 241-262.

Donaldson T. \& Preston L.E. 1995. The stakeholder theory of the corporation: Concepts, Evidence, and Implications, Academy of Management Review, 20(1): 65-91.

Dosi G. 1997. Opportunities, Incentives and the Collective Patterns of Technological Change, Economic Journal, Royal Economic Society, 107(444), 1530-1547.

Hamel G. \& Prahalad C. K. 1989. Strategic Intent, Harvard Business Review, 67(3): 6378.

Husted B.W. \& Allen D.B. 2007a. Corporate Social Strategy in Multinational Enterprises: Antecedents and Value Creation, Journal of Business Ethics, 74: 34-361.

Husted B.W. \& Allen D.B. 2007b. Strategic Corporate Social Responsibility and Value Creation among Large Companies, Long Range Planning, 40: 594-610.

Jenkins H. 2006. Small Business Champions for Corporate Social Responsibility, Journal of Business Ethics, 67: 241-256.

Le Bas C., Poussing N. \& Haned N. 2010. Innovation, leadership technologique et comportements de responsabilité sociale. Une exploration sur données d'entreprises. Economies et Sociétés. № 12, Série W, 1363-1386. 
McWilliams A. \& Siegel D.S. 2000. Corporate social responsibility and financial performance: correlation or misspecification?, Strategic Management Journal, 21(5): 603-609.

Mohnen, P. \& Mairesse, J. 2010. Using Innovations Surveys of Econometric Analysis. NBER Working Paper No.15857, April, 2- 40.

Mohnen P. \& Roller L. 2005. Complementarities in innovation policy, European Economic Review, 49(6): 1431-1450.

Moore G., Slack R. \& Gibbon J. 2009. Criteria for Responsible Business Practice in SMEs: An Exploratory Case of U.K. Fair Trade Organisations, Journal of Business Ethics, 89: 173-188.

Moore G. \& Spence L. 2006. Editorial: Responsibility and Small Business, Journal of Business Ethics, 67: 219-226.

Morimune K. 1979. Comparisons of Normal and Logistic Models in the Bivariate Dichitomous Analysis, Econometrica, 47: 957-975.

Murillo D. \& Lozano J.M. 2006. SMEs and CSR: An Approach to CSR in their Own Words, Journal of Business Ethics, 67: 227-240.

Nelson R.R. \& Winter S.G. 1982. An Evolutionary Theory of Economic Change, Harvard University Press Cambridge Mass.

Nidumolu R., Prahalad C.K. \& Rangaswami M.R. 2009. Why sustainability is now the key driver of innovation, Harvard Business Review, September, 56-64.

Porter M.E. \& Kramer M.R. 2006. Strategy and Society, Harvard Business Review, December, 77-92.

Sharma, S. \& Vredenburg H. 1998. Proactive corporate environmental strategy and the development of competitively valuable organizational capabilities.Strategic Management Journal, 19: 729-753.

Teece D. J. \& Pisano G. 1994. The dynamic Capabilities of Firms: An Introduction, Industrial and Corporate Change, 3: 537-556.

Tencati A., Perrini F. \& Pogutz S. 2004. New Tools to Foster Corporate Socially Responsible Behavior, Journal of Business Ethics, 53: 173-190. 


\section{Appendix 1 Descriptive statistics}

\begin{tabular}{|c|c|c|c|c|}
\hline & & & $\begin{array}{l}\text { Sample } \\
(n=266)\end{array}$ & $\begin{array}{c}\text { Weighted } \\
\text { Data } \\
(n=1431)\end{array}$ \\
\hline Variables & Min & Max & $\begin{array}{c}\text { Mean } \\
\text { Standard error }\end{array}$ & $\begin{array}{c}\text { Mean } \\
\text { Standard error }\end{array}$ \\
\hline INPDGD & 0 & 1 & $\begin{array}{c}0.42481203 \\
(0.49524623)\end{array}$ & $\begin{array}{c}0.36157943 \\
(1.11654759)\end{array}$ \\
\hline INSPSPD & 0 & 1 & $\begin{array}{c}0.32706767 \\
(0.47002655)\end{array}$ & $\begin{array}{c}0.3377076 \\
(1.09904948)\end{array}$ \\
\hline INORG & 0 & 1 & $\begin{array}{c}0.56766917 \\
(0.49633356)\end{array}$ & $\begin{array}{c}0.53438103 \\
(1.1592118)\end{array}$ \\
\hline CLUSTER_1 & 0 & 1 & $\begin{array}{l}0.10526316 \\
(0.3074707) \\
\end{array}$ & $\begin{array}{c}0.09591498 \\
(0.68433666) \\
\end{array}$ \\
\hline CLUSTER_2 & 0 & 1 & $\begin{array}{c}0.14661654 \\
(0.35439001)\end{array}$ & $\begin{array}{c}0.12959299 \\
(0.78050177)\end{array}$ \\
\hline PLAN_RSE & 0 & 1 & $\begin{array}{c}0.14661654 \\
(0.35439001)\end{array}$ & $\begin{array}{c}0.13267664 \\
(0.78833299)\end{array}$ \\
\hline NO_RSE & 0 & 1 & $\begin{array}{c}0.60150376 \\
(0.49051147)\end{array}$ & $\begin{array}{c}0.64181539 \\
(1.11424442)\end{array}$ \\
\hline $\mathrm{T} 1$ & 0 & 1 & $\begin{array}{c}0.43984962 \\
(0.49730441)\end{array}$ & $\begin{array}{c}0.72616142 \\
(1.03630083)\end{array}$ \\
\hline $\mathrm{T} 2$ & 0 & 1 & $\begin{array}{c}0.39849624 \\
(0.49051147)\end{array}$ & $\begin{array}{c}0.22064017 \\
(0.96368088)\end{array}$ \\
\hline $\mathrm{T} 3$ & 0 & 1 & $\begin{array}{c}0.16165414 \\
(0.36882717)\end{array}$ & $\begin{array}{c}0.05319841 \\
(0.52155579)\end{array}$ \\
\hline INDUS & 0 & 1 & $\begin{array}{c}0.42105263 \\
(0.49465866)\end{array}$ & $\begin{array}{c}0.21843196 \\
(0.96020382)\end{array}$ \\
\hline NEMPHI & 0 & 1 & $\begin{array}{c}0.26393752 \\
(0.31063712)\end{array}$ & $\begin{array}{c}0.29231013 \\
(0.71749629)\end{array}$ \\
\hline GROUPE & 0 & 1 & $\begin{array}{c}0.5037594 \\
(0.50092835)\end{array}$ & $\begin{array}{c}0.46 \mathrm{bbbb} 705088 \\
(1.15943636)\end{array}$ \\
\hline NMARCONC & 1 & 1 & $\begin{array}{l}0.59774436 \\
(0.4912773)\end{array}$ & $\begin{array}{c}0.60810426 \\
(1.13447842)\end{array}$ \\
\hline
\end{tabular}




\section{Appendix 2 Table of correlation between the variables}

\begin{tabular}{|c|c|c|c|c|c|c|}
\hline \multicolumn{7}{|c|}{$\begin{array}{c}\text { Pearson Correlation Coefficients, } N=266 \\
\text { Prob }>|r| \text { under HO: } R h 0=0\end{array}$} \\
\hline & INPDT & INPCS & inorg & n_classe_1 & n_classe_2 & projrse \\
\hline INPDT & 1 & & & & & \\
\hline INPCS & $\begin{array}{c}0.45458 \\
<.0001\end{array}$ & 1 & & & & \\
\hline inorg & $\begin{array}{c}0.36619 \\
<.0001\end{array}$ & $\begin{array}{l}0.25254 \\
<.0001\end{array}$ & 1 & & & \\
\hline n_classe_1 & $\begin{array}{c}0.07695 \\
0.2109\end{array}$ & $\begin{array}{c}0.07421 \\
0.2277\end{array}$ & $\begin{array}{c}-0.07158 \\
0.2447\end{array}$ & 1 & & \\
\hline n_classe_2 & $\begin{array}{l}0.2458 \\
<.0001\end{array}$ & $\begin{array}{c}0.09615 \\
0.1177\end{array}$ & $\begin{array}{c}0.16864 \\
0.0058\end{array}$ & $\begin{array}{c}-0.14217 \\
0.0204\end{array}$ & 1 & \\
\hline projrse & $\begin{array}{c}-0.03371 \\
0.5842\end{array}$ & $\begin{array}{l}0.00554 \\
0.9284\end{array}$ & $\begin{array}{c}0.03992 \\
0.5168\end{array}$ & $\begin{array}{c}-0.14217 \\
0.0204\end{array}$ & $\begin{array}{c}-0.17181 \\
0.005\end{array}$ & 1 \\
\hline pasrse & $\begin{array}{c}-0.20148 \\
0.001\end{array}$ & $\begin{array}{c}-0.11999 \\
0.0506\end{array}$ & $\begin{array}{c}-0.10582 \\
0.085\end{array}$ & $\begin{array}{l}-0.4214 \\
<.0001\end{array}$ & $\begin{array}{c}-0.50924 \\
<.0001\end{array}$ & $\begin{array}{c}-0.50924 \\
<.0001\end{array}$ \\
\hline petite & $\begin{array}{c}-0.19463 \\
0.0014\end{array}$ & $\begin{array}{c}-0.10117 \\
0.0997\end{array}$ & $\begin{array}{c}-0.17455 \\
0.0043\end{array}$ & $\begin{array}{c}-0.13119 \\
0.0325\end{array}$ & $\begin{array}{c}-0.17459 \\
0.0043\end{array}$ & $\begin{array}{c}0.01811 \\
0.7687\end{array}$ \\
\hline moy & $\begin{array}{c}0.04613 \\
0.4537\end{array}$ & $\begin{array}{l}0.03815 \\
0.5356\end{array}$ & $\begin{array}{c}0.05932 \\
0.3352\end{array}$ & $\begin{array}{c}0.04609 \\
0.4541\end{array}$ & $\begin{array}{c}-0.05517 \\
0.3701\end{array}$ & $\begin{array}{c}0.00996 \\
0.8716\end{array}$ \\
\hline grde & $\begin{array}{c}0.20108 \\
0.001\end{array}$ & $\begin{array}{c}0.08568 \\
0.1635\end{array}$ & $\begin{array}{c}0.15646 \\
0.0106\end{array}$ & $\begin{array}{c}0.11559 \\
0.0597\end{array}$ & $\begin{array}{l}0.30878 \\
<.0001\end{array}$ & $\begin{array}{c}-0.03766 \\
0.5408\end{array}$ \\
\hline indus & $\begin{array}{c}0.11431 \\
0.0626\end{array}$ & $\begin{array}{c}0.15205 \\
0.013\end{array}$ & $\begin{array}{c}-0.03964 \\
0.5198\end{array}$ & $\begin{array}{c}-0.09402 \\
0.1261\end{array}$ & $\begin{array}{c}0.05551 \\
0.3671\end{array}$ & $\begin{array}{c}-0.07364 \\
0.2313\end{array}$ \\
\hline groupe & $\begin{array}{c}0.24452 \\
<.0001\end{array}$ & $\begin{array}{l}0.13099 \\
0.0327\end{array}$ & $\begin{array}{l}0.1811 \\
0.003\end{array}$ & $\begin{array}{c}-0.07608 \\
0.2162\end{array}$ & $\begin{array}{l}0.24134 \\
<.0001\end{array}$ & $\begin{array}{l}0.02877 \\
0.6404\end{array}$ \\
\hline nemphi & $\begin{array}{c}0.29986 \\
<.0001\end{array}$ & $\begin{array}{l}0.0599 \\
0.3304\end{array}$ & $\begin{array}{l}0.25655 \\
<.0001\end{array}$ & $\begin{array}{c}0.10867 \\
0.0769\end{array}$ & $\begin{array}{c}0.07453 \\
0.2257\end{array}$ & $\begin{array}{c}0.04456 \\
0.4693\end{array}$ \\
\hline nmarconc & $\begin{array}{l}0.0846 \\
0.1689\end{array}$ & $\begin{array}{c}0.13067 \\
0.0331\end{array}$ & $\begin{array}{c}0.16622 \\
0.0066\end{array}$ & $\begin{array}{c}0.05654 \\
0.3584\end{array}$ & $\begin{array}{c}0.03659 \\
0.5525\end{array}$ & $\begin{array}{c}0.03659 \\
0.5525\end{array}$ \\
\hline
\end{tabular}




\begin{tabular}{|c|c|c|c|c|c|c|c|c|}
\hline \multicolumn{9}{|c|}{$\begin{array}{c}\text { Pearson Correlation Coefficients, } \mathrm{N}=266 \\
\text { Prob }>|\mathrm{r}| \text { under } \mathrm{HO}: \mathrm{Rho}=0\end{array}$} \\
\hline & pasrse & petite & moy & grde & indus & groupe & nemphi & nmarconc \\
\hline pasrse & 1 & & & & & & & \\
\hline \multirow[t]{2}{*}{ petite } & 0.19529 & 1 & & & & & & \\
\hline & 0.0014 & & & & & & & \\
\hline \multirow[t]{2}{*}{ moy } & 0.00377 & -0.72126 & 1 & & & & & \\
\hline & 0.9512 & $<.0001$ & & & & & & \\
\hline \multirow[t]{2}{*}{ grde } & -0.26834 & -0.38912 & -0.35742 & 1 & & & & \\
\hline & $<.0001$ & $<.0001$ & $<.0001$ & & & & & \\
\hline \multirow[t]{2}{*}{ indus } & 0.07203 & -0.0654 & 0.02128 & 0.05987 & 1 & & & \\
\hline & 0.2417 & 0.2879 & 0.7297 & 0.3307 & & & & \\
\hline \multirow[t]{2}{*}{ groupe } & -0.14746 & -0.42323 & 0.25496 & 0.23158 & 0.06973 & 1 & & \\
\hline & 0.0161 & $<.0001$ & $<.0001$ & 0.0001 & 0.2571 & & & \\
\hline \multirow[t]{2}{*}{ nemphi } & -0.15415 & -0.10705 & 0.05006 & 0.07776 & -0.3099 & 0.13923 & 1 & \\
\hline & 0.0118 & 0.0814 & 0.4161 & 0.2062 & $<.0001$ & 0.0231 & & \\
\hline \multirow[t]{2}{*}{ nmarconc } & -0.08831 & 0.00099 & -0.02131 & 0.02701 & 0.00082 & 0.05984 & -0.01774 & 1 \\
\hline & 0.1509 & 0.9872 & 0.7294 & 0.661 & 0.9894 & 0.331 & 0.7733 & \\
\hline
\end{tabular}


Appendix 3

Biprobit regression results for the weighted sample: Determinants of Innovation Behavior

\begin{tabular}{|c|c|c|}
\hline & \multicolumn{2}{|c|}{ Dependent Variables } \\
\hline \multirow{2}{*}{ Independent Variables } & \multicolumn{2}{|c|}{ Coefficient (standard error) } \\
\hline & INPDGD & INSPSPD \\
\hline CLUSTER_1 & $\begin{array}{l}0.374872 * * * \\
(0.1329594)\end{array}$ & $\begin{array}{c}0.4106931 * * * \\
(0.1375318)\end{array}$ \\
\hline CLUSTER_2 & $\begin{array}{c}0.1098827 \\
(0.1167831)\end{array}$ & $\begin{array}{c}-0.5523364 * * * \\
(0.1316845)\end{array}$ \\
\hline PLAN_RSE & $\begin{array}{c}-0.3373036^{* * *} \\
(0.111329)\end{array}$ & $\begin{array}{l}-0.1933346^{*} \\
(0.1104697)\end{array}$ \\
\hline NO_RSE & Ref. & Ref. \\
\hline $\mathrm{T} 1$ & $\begin{array}{c}-0.2515084 * * * \\
(0.0947228)\end{array}$ & $\begin{array}{l}-0.1120048 \\
(0.0956208)\end{array}$ \\
\hline $\mathrm{T} 2$ & Ref. & Ref. \\
\hline T3 & $\begin{array}{l}0.339528^{* *} \\
(0.1749723)\end{array}$ & $\begin{array}{l}-0.1358122 \\
(0.1741876)\end{array}$ \\
\hline INDUS & $\begin{array}{c}0.3756193 * * * \\
(0.0917972)\end{array}$ & $\begin{array}{c}0.4448112 * * * \\
(0.0921797)\end{array}$ \\
\hline GROUPE & $\begin{array}{c}0.2253724^{* * *} \\
(0.078771)\end{array}$ & $\begin{array}{c}0.6272012^{* * *} \\
(0.081476)\end{array}$ \\
\hline EDUCATION & $\begin{array}{l}1.437808 * * * \\
(0.1227998)\end{array}$ & $\begin{array}{l}1.309196^{* * * *} \\
(0.1229809)\end{array}$ \\
\hline NMARCONC & $\begin{array}{c}0.2409803 * * * \\
(0.0769115)\end{array}$ & $\begin{array}{c}0.4205952 * * * \\
(0.0784566)\end{array}$ \\
\hline Constante & $\begin{array}{c}-0.9855721 * * * \\
(0.1185309)\end{array}$ & $\begin{array}{c}-1.373902 * * * \\
(0.1227475)\end{array}$ \\
\hline Sample size & & \\
\hline Log-likelihood & & \\
\hline Rho & & \\
\hline$\overline{\mathrm{P}>}>\mathrm{z} \mid$ & & \\
\hline
\end{tabular}

*** significant at $1 \%$ level $; * *$ significant at $5 \%$ level 